\title{
Mesozooplankton of an Impacted Bay in North Eastern Brazil
}

\author{
Andréa Pinto Silva, Sigrid Neumann-Leitão*, Ralf Schwamborn, Lúcia Maria de Oliveira \\ Gusmão and Tâmara de Almeida e Silva \\ Departamento de Oceanografia; Universidade Federal de Pernambuco; Av. Arquitetura s/n; Cidade Universitária; \\ 50730-540; sigrid@terra.com.br; Recife-PE-Brazil
}

\begin{abstract}
Mesozooplankton abundance and distribution at Suape Bay, Pernambuco, was studied to assess the impacts caused by the construction of an internal port to increase the capacity of the Suape Port Complex. Zooplankton sampling was done at 3 stations during the dry (November-December/1997) and rainy (April-May/1998) seasons. A plankton net with $300 \mu \mathrm{m}$ mesh size was used. Wet weight plankton biomass ranged from $44 \mathrm{mg} . \mathrm{m}^{-3}$ to $3,638 \mathrm{mg} \cdot \mathrm{m}^{-3}$. Fortyfive macrozooplankton taxa were registered. The most abundant was Copepoda. Among copepods, Acartia lilljeborgi, Parvocalanus crassirostris, Oithona hebes, Corycaeus (C.) speciosus and Temora turbinata were most frequent. Minimum abundance was 9 ind. $\mathrm{m}^{-3}$ and maximum was 2,532 ind. $\mathrm{m}^{-3}$. Average species diversity was 2.55 bits.ind ${ }^{-1}$. As a whole, Suape Bay has been under severe environmental stress and it seemed reasonable to assume that the recent modifications of the basin have resulted in changes in species composition and trophic structure, with an increase in marine influence.
\end{abstract}

Key words: Mesozooplankton, Copepoda, human impacts, Suape Port Complex

\section{INTRODUCTION}

On the coast of Pernambuco State, Brazil, an industrial port complex was created in 1979/1980 as an attempt to solve the collapse of the State's economy. This port complex was built in Suape Bay. In order to evaluate ecosystem changes, an Ecological Research Program was created. Studies performed before the port's implementation (Melo Filho, 1977; Lima and Costa, 1978; Cavalcanti et al., 1980; Ramos-Porto and Lima, 1983; Neumann-Leitão et al., 1992a) revealed a highly productive, balanced environment. In some of these studies, suggestions were made to minimize impacts, although none of them were considered.
After the port's implementation, ecological studies carried out from 1986 to 1994 by the Departament of Oceanography of the Federal University of Pernambuco focussed on the estuary of the Ipojuca River, the main freshwater source in the area, in order to assess possible impacts. Among these impacts, landfills, dredging and constructions had the most obvious impact on the area's geomorphology, hydrodynamics and plankton. Irregular fluctuations in the plankton community were registered with a sharp decrease in phytoplankton, mollusk, crustacean and fish larvae. The human impacts affected the system balance and resilience (Neumann-Leitão et al., 1992a; Neumann et al., 1998). From 1997 to 1998, further ecological studies were carried out at

\footnotetext{
* Author for correspondence
} 
Suape Bay to assess the impacts caused by the construction of an internal port to increase the capacity of the Suape Port Complex.

The objective of this study was to summarize the mesozooplankton composition and abundance.

\section{MATERIALS AND METHODS}

\section{Study area}

Suape Bay is located between $8^{\circ} 15^{\prime}-8^{\circ} 30^{\prime} \mathrm{S}$ and $34^{\circ} 55^{\prime}-35^{\circ} 05^{\prime} \mathrm{W}$, about $40 \mathrm{~km}$ south of Recife City (Fig. 1). Climate is warm-humid, pseudotropical (Koppen As') with a mean annual temperature of $24^{\circ} \mathrm{C}$ and a rainfall of $1500-2000$ $\mathrm{mm} . \mathrm{yr}^{-1}$, concentrated from March to August.

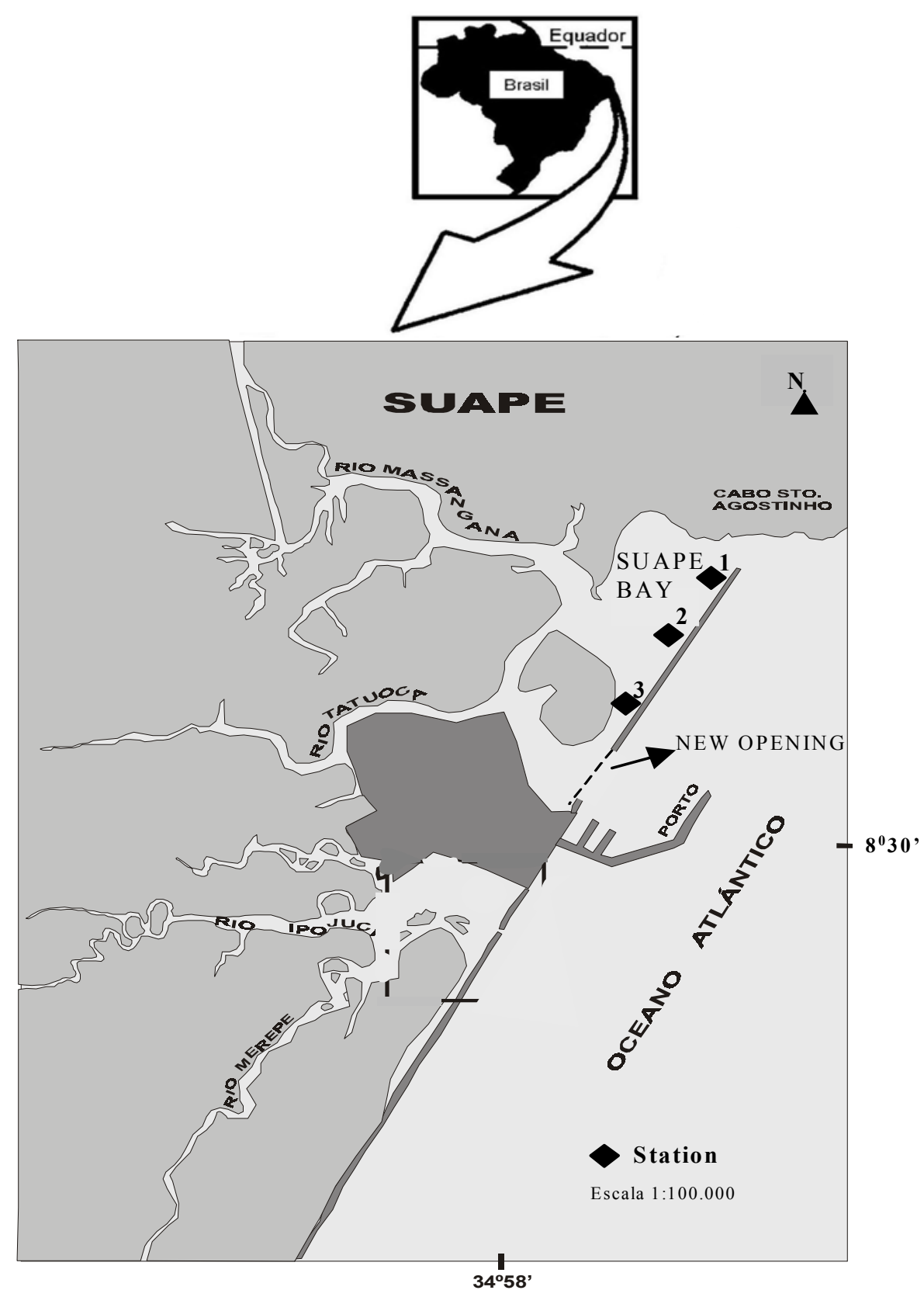

Figure 1 - Studied area of Suape (Pernambuco, Brazil) and stations localization. 
Humidity is higher than $80 \%$. Predominant winds are from the southeast. The original Atlantic rainforest has been largely replaced by sugar cane culture. Before the port's implementation, four rivers (Massangana, Tatuoca, Ipojuca and Merepe rivers) drained into Suape Bay, itself an estuary partly isolated from the ocean by an extensive sandstone reefline with $15 \mathrm{Az}$ direction. Today, only the Massangana and Tatuoca rivers still drain into Suape Bay. The rivers Ipojuca and Merepe had their connection with the bay interrupted by intensive embankment to build the Port Complex (Neumann et al., 1998). In the Suape area, more than 600 hectares of mangrove have been destroyed.

\section{Methods}

Zooplankton sampling at Suape Bay was done at 3 hours interval during a full tidal cycle at 3 stations located along the reefline during the dry (November-December/1997) and rainy (AprilMay/1998) seasons, during spring tide. A plankton net $(1.5 \mathrm{~m}$ length, $60 \mathrm{~cm}$ mouth diameter) with $300 \mu \mathrm{m}$ mesh size was used. Horizontal subsurface hauls were made at each station for 3 minutes. A flowmeter (Hydrobios, Kiel) was fitted onto the opening of the net. The 48 samples collected were preserved in $4 \%$ buffered formaldehyde/seawater solution. Biomass was estimated by the wet weight (WW) method (Omori and Ikeda, 1984). Zooplankton species were identified (Tregouboff and Rose, 1957; Boltovskoy, 1981, 1999, among other identification manuals) and taxon abundance per cubic meter was determined from a $10 \mathrm{ml}$ subsample, taken with a Stempel-pipette of the entire sample $(500 \mathrm{ml})$. The Shannon diversity index was applied for the estimation of community diversity (Shannon, 1948) and the evenness was calculated according to Pielou (1977).

\section{RESULTS}

Plankton biomass varied from $44 \mathrm{mgWW} \cdot \mathrm{m}^{-3}$ (station 2, high tide, December/1997) to 3,638 mgWW.m ${ }^{-3}$ (station 3, ebb tide, May/1998). This high biomass was caused by a high load of fine sediment due the dredging activity in the port.

Forty-five mesozooplankton taxa were registered at Suape Bay (Table 1). The most abundant taxa at the dry season were copepods $(70 \%$ to $90 \%$ dominance) and at the rainy season, copepods and decapod larvae. The remaining taxa showed mean relative abundances lower than $10 \%$. Among the copepods, the species Acartia lilljeborgi, Parvocalanus crassirostris, Oithona hebes, Corycaeus (C.) speciosus and Temora turbinata were frequent at Suape Bay (Table 1). Other frequent taxa were Sagitta tenuis, Oikopleura dioica, and brachyuran zoeae. The mesozooplankton composition in November/1997 (before reef breakup), was characterized by an estuarine group dominated by Acartia lilljeborgi, Parvocalanus crassirostris, Oithona hebes, $O$. oswaldocruzi and Euterpina acutifrons. In December/1997 and ongoing months (during and after reef breakup) a coastal marine group such as Paracalanus quasimodo, P. indicus, Calanopia americana, Oncaea venusta, Corycaeus (C.) speciosus and Microsetella rosea began to occur at Suape Bay.

Zooplankton minimum abundance was 9 ind. $\mathrm{m}^{-3}$, (high tide, station 1, rainy season, May/1998) and maximum was 2,532 ind. $\mathrm{m}^{-3}$ (ebb tide, station 3, dry season, november/1997). The species Acartia lilljeborgi was by far the most abundant $(2,076$ ind. $\mathrm{m}^{-3}$ ), with an average density of 1,900 ind. $\mathrm{m}^{-3}$. Station 1 presented two large peaks in November, one at low tide and another one during high tide (Fig. 2).

Station 2 presented two smaller peaks in April, one during ebb and another during flood tides. Station 3 had two high peaks in November (ebb and low tide) and one small in May (flood) (Fig. 2).

Species diversity varied from 0.77 bits.ind $^{-1}$ (station 1, low tide, May/1998) caused by the dominance of brachyuran zoeae, to 3.87 (station 3, high tide, April/1998) (Fig. 3a). Average diversity was 2.55 bits.ind $^{-1}$. Evenness varied from 0.28 (station 3, ebb, November/1997) to 0.95 (station 2, low tide, December/1997) (Fig. 3b); average was 0.68 . 


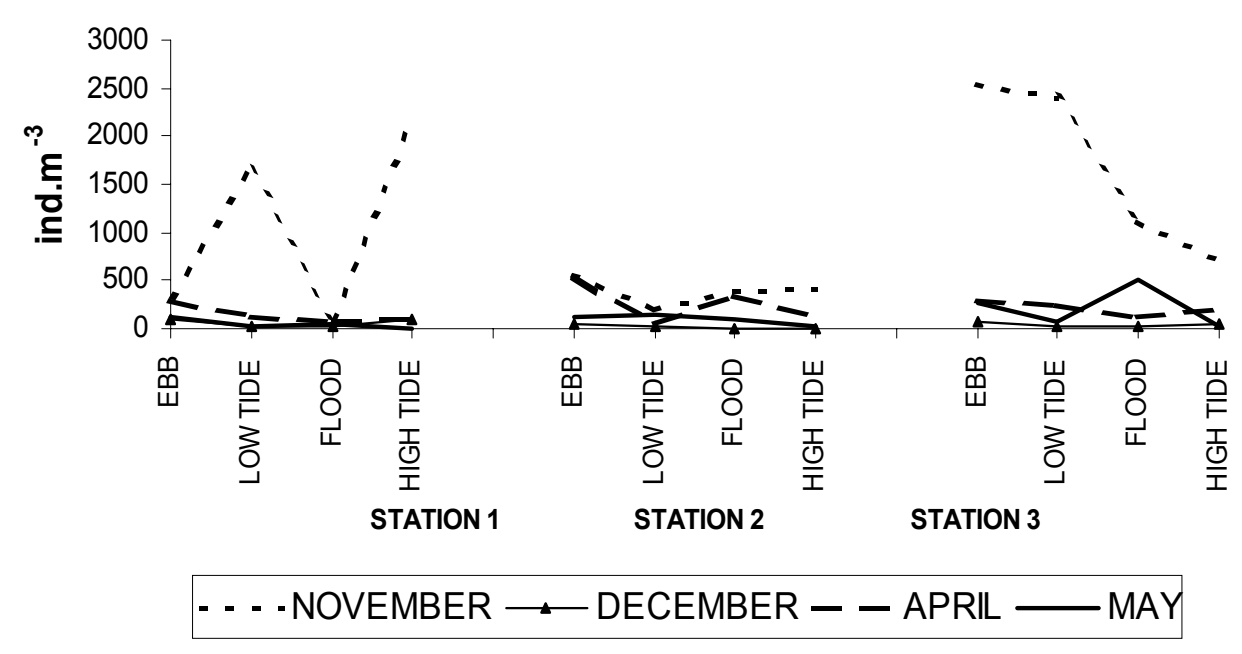

Figure 2 - Mesozooplankton abundance at Suape Bay, Pernambuco (Brazil) during the dry (November-December/1997) and rainy (April-May/1998) seasons.
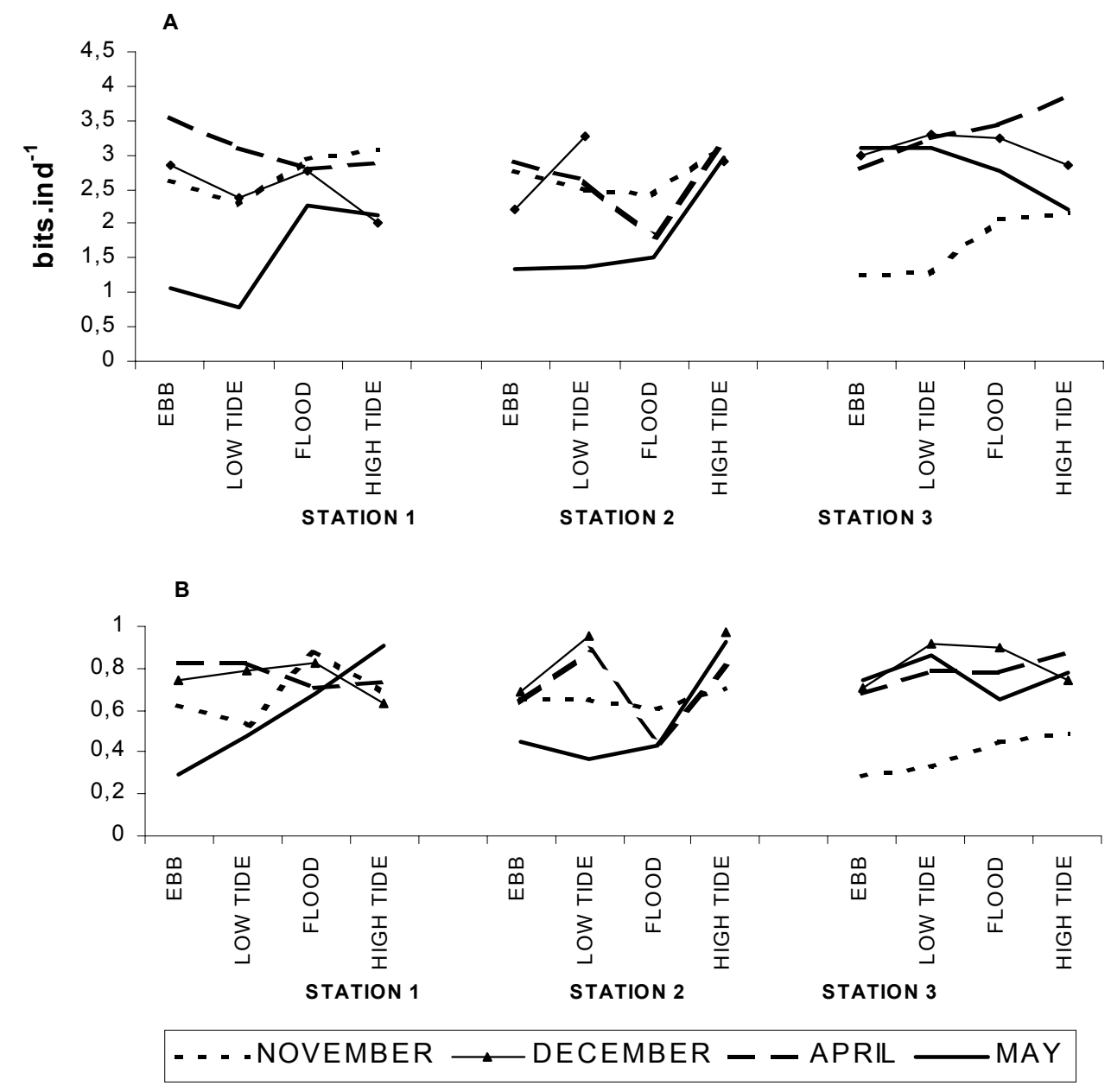

Figure 3 - Mesozooplankton Shannon species diversity (A) and Evenness (B) at Suape Bay, Pernambuco (Brazil) during the dry (November-December/1997) and rainy (AprilMay/1998) seasons. 
Table 1 - Mesozooplankton of Suape Bay, Pernambuco (Brazil) during the dry (November-December/1997) and rainy (April-May/1998) seasons. $\mathrm{AD}=$ Average density $\left(\right.$ ind. $\left.\mathrm{m}^{-3}\right), \mathrm{FO}=$ frequency of Occurrence.

\begin{tabular}{|c|c|c|}
\hline FORAMINIFERA & AD & FO \\
\hline Tretomphalus bulloides d'Orbigny, 1826 & 1 & 2.13 \\
\hline Quinqueloculina sp. & 1 & 2.13 \\
\hline \multicolumn{3}{|l|}{ CNIDARIA } \\
\hline Hydromedusa & 12 & 25.53 \\
\hline \multicolumn{3}{|l|}{ ASCHELMINTHES } \\
\hline Nematoda & 2 & 8.51 \\
\hline \multicolumn{3}{|l|}{ MOLLUSCA } \\
\hline Gastropoda (larvae) & 40 & 31.91 \\
\hline Bivalvia (larvae) & 2 & 21.28 \\
\hline \multicolumn{3}{|l|}{ ANNELIDA } \\
\hline Polychaeta (larvae) & 9 & 44.68 \\
\hline \multicolumn{3}{|l|}{ CRUSTACEA } \\
\hline \multicolumn{3}{|l|}{ Calanoida } \\
\hline Parvocalanus crassirostris F. Dahl,1894 & 65 & 74.47 \\
\hline Paracalanus quasimodo Bowman, 1971 & 669 & 48.94 \\
\hline Paracalanus indicus Wolfenden, 1905 & 41 & 48.94 \\
\hline Temora turbinata (Dana, 1849) & 93 & 70.21 \\
\hline Temora stylifera (Dana, 1848) & 1 & 21.28 \\
\hline Pseudodiaptomus acutus (F. Dahl,1894) & 65 & 27.66 \\
\hline Pseudodiaptomus richardi (F. Dahl,1894) & 3 & 34.04 \\
\hline Labidocera fluviatilis F. Dahl, 1894 & 21 & 19.15 \\
\hline Calanopia americana F. Dahl, 1894 & 118 & 74.47 \\
\hline Acartia lilljeborgi Giesbrecht, 1892 & 1900 & 78.72 \\
\hline \multicolumn{3}{|l|}{ Cyclopoida } \\
\hline Oithona nana Giesbrecht, 1892 & 1 & 12.77 \\
\hline Oithona hebes Giesbrecht, 1892 & 50 & 78.72 \\
\hline \multicolumn{3}{|l|}{ Haparcticoida } \\
\hline Microsetella rosea (Dana, 1848) & 1 & 2.13 \\
\hline Euterpina acutifrons (Dana, 1852) & 13 & 34.04 \\
\hline Metis sp. & 5 & 12.77 \\
\hline Tigriopus sp. & 1 & 10.64 \\
\hline Tisbe sp. & 1 & 2.13 \\
\hline \multicolumn{3}{|l|}{ Poecilostomatoida } \\
\hline Oncaea venusta Philippi, 1843 & 1 & 21.28 \\
\hline Corycaeus (Corycaeus) speciosus Dana, 1849 & 55 & 74.47 \\
\hline Copepoda (nauplius) & 9 & 14.89 \\
\hline \multicolumn{3}{|l|}{ Cirripedia } \\
\hline Balanus sp. (nauplius) & 105 & 53.19 \\
\hline Balanus sp. (cypris) & 63 & 36.17 \\
\hline \multicolumn{3}{|l|}{ Isopoda } \\
\hline Epicaridae (larvae) & 4 & 6.38 \\
\hline Amphipoda (protozoeae) & 2 & 6.38 \\
\hline \multicolumn{3}{|l|}{ Decapoda } \\
\hline Sergestidae & 3 & 12.77 \\
\hline Lucifer faxoni Borradaile, 1915 & 47 & 42.55 \\
\hline Alpheidae (larvae) & 6 & 44.68 \\
\hline Porcellanidae (larvae) & 1 & 6.38 \\
\hline Paguridae (larvae) & 22 & 46.81 \\
\hline Brachyura (zoeae) & 255 & 48.94 \\
\hline Decapoda (other larvae) & 16 & 34.04 \\
\hline Stomatopoda (larvae) & 3 & 31.91 \\
\hline \multicolumn{3}{|l|}{ CHAETOGNATHA } \\
\hline Sagitta tenuis Conant, 1896 & 68 & 70.21 \\
\hline
\end{tabular}




\begin{tabular}{lrr} 
Cont. table 1 & & \\
\hline CHORDATA & 235 & 76.60 \\
Larvacea & 1 & 6.38 \\
Oikopleura dioica Fol, 1872 & 38 & 76.60 \\
Ascideacea (larvae) & 38 \\
Osteichthyes & \\
Teleostei (eggs and larvae)
\end{tabular}

\section{DISCUSSION}

Mesozooplankton was dominated by Copepoda, which made up nearly $73 \%$ of total abundance. The dominance of Copepoda in Brazilian tropical estuaries has already been described by Tundisi (1970), Björnberg (1981) and Neumann-Leitão (1995). The most abundant species found in the present work were typical of coastal waters (Boltovskoy,1981), showing that the intense marine influx in Suape Bay, after the reef breakage, mainly at station 3, affected the zooplankton composition. High densities of

Acartia lilljeborgi, an estuarine copepod (Björnberg, 1981) were registered mainly in November/1997, before the reef breakage, when a typical estuarine community occurred in the bay.

In general, the zooplankton abundance of the studied area was low, when comparing to other estuaries of Pernambuco collected with the same mesh size net (Schwamborn, 1997; Neumann-Leitão et al., 2001; Schwamborn et al., 2001 among others), even when comparing with the earlier data of Paranaguá (1986) for this area. Lower values were registered after November 1997, when the port expansion began. The microzooplankton abundance (net $65 \mu \mathrm{m}$ mesh size) of the estuaries of the rivers Massangana and Tatuoca, which outflux into Suape Bay, was also very low after the port construction vaying from 12 to 100 org. $\mathrm{m}^{-3}$ (Neumann-Leitão et al., 1992b).

This low abundance could be possibly a consequence of the high load of suspended material caused by the continuous dredging (Jonge, 1983; Neumann et al., 1998), what would affect primary productivity due to light intensity reduction (Koening et al., 2002). High loads of nutrients at the Suape ecosystem caused by anthropogenic inputs in Suape Bay, could favor the phytoplankton growth, but the turbid waters would limit the primary production. As most of the estuarine zooplankton collected with plankton net are thought to be herbivorous (Day Jr et al.,
1989), the low density of food available for grazing at Suape Bay might have caused the low zooplankton density observed.

Some authors have suggested that suspended organic detritus was an important secondary food source for estuarine zooplankton (Heinle and Flemer, 1975; Day Jr et al., 1982; Roman, 1984 among others). In the Itamaracá estuarine system (northern coast of Pernambuco State), the importance of mangrove detritus for estuarine macrozooplankton was demonstrated by Schwamborn (1997) through stable isotope analysis and laboratory feeding experiments. Stable isotope measurements have shown that an amount of $13 \%$ to $40 \%$ of the carbon assimilated by estuarine copepods was of mangrove origin. In Suape Bay however, the destruction of 600 hectares of mangrove (Braga et al., 1989) affected the availability of organic detritus, thus limiting another food source for the zooplankton.

Brachyuran zoeae, fish larvae and eggs were very abundant at the Suape area before port implantation (Paranaguá, 1986), but nowadays, although frequent in the rainy season, they occurred in low abundances, showing a deficiency in larval recruitment. This was probably caused by the continuous human impacts related to the port expansion.

At Suape Bay, intermediate values of diversity were found, although we expected a lower diversity, as the number of species should decrease due to the instability of the environmental variables. According to Giller (1984), environmental fluctuations increased the probability of a species becoming extinct. This suggested that the underlying cause of high diversity was the persistence of stable environmental conditions over long periods of time, allowing communities to become biologically accommodated with smaller nonoverlapping niches (MacArthur, 1972; Planka, 1978). On the other hand, some authors (Ricklefs, 1980; Connell, 1980, among others) believed that disturbance rather than stability seemed to enhance 
species richness under certain conditions. Species equilibrium, in accordance with the habitat's carrying capacity, could never be attained if the habitat was frequently disturbed. Such disturbances are indiscriminate, and may remove a large proportion or all individuals from an area. However, if disturbances are rare and small, they have little impact and competition leads to the elimination of inferior competitors as the community moves to equilibrium. There is more time for the invasion of species to the disturbed area, insufficient time for intensive competitive elimination to occur, and a greater range of species from all succession stages and of all competitive abilities is maintained. The intermediate disturbance hypothesis has been suggested as the explanation for the high diversity of tropical rainforest trees and coral reefs (Connell, 1978). As a whole, Suape Bay is under severe environmental stress and it seems reasonable to assume that the recent modifications of the basin resulted in changes in the species composition and trophic structure, with an increase in marine influence. The tidal influx carries marine species (such as Paracalanus quasimodo, P. indicus, Calanopia americana, Oncaea venusta, Corycaeus (C.) speciosus and Microsetella rosea) increasing species diversity and evenness during high-tide, mainly at station 3 , which exhibited highest average diversity $\left(2.73\right.$ bits.ind $\left.^{-1}\right)$. Through time, such changes may result in a completely new trophic structure.

Human activities have been the main cause of nonindigenous species being introduced to new areas in the last century (Carlton, 1989), and in aquatic ecosystems shipping has enabled the invasion of species that survive in ballast water into areas similar to their native habitats (Carlton and Hodder, 1995). The presence of the copepod Temora turbinata at Suape Bay, which did not occur in Northeastern Brazil before 1993 (Araújo and Montú, 1993) and now dominates several coastal areas and estuaries of Brazil, may be caused by ship ballast water at the Suape port. However, more studies are necessary to confirm this hypothesis. This is a very relevant subject to be studied, since in the future, even more invasive species may occur, which may affect the zooplankton structure in a negative way.

\section{RESUMO}

A abundância e a distribuição do mesozooplâncton na baía de Suape, Pernambuco, foram estudadas objetivando-se levantar os impactos causados pela construção de um porto interno para aumentar a capacidade do Complexo Portuário de Suape. Amostragens do zooplâncton foram feitas em três estações fixas, nos períodos seco (novembrodezembro/1997) e chuvoso (abril-maio/1998). Uma rede de plâncton com $300 \mu \mathrm{m}$ de abertura de malha foi usada. A biomassa do plâncton em termos de peso úmido variou de $44 \mathrm{mg} . \mathrm{m}^{-3}$ a 3.638 mg. $\mathrm{m}^{-3}$. Foram registrados 45 taxa zooplanctônicos, sendo Copepoda o mais abundante. Dentre os copépodes destacaram-se em termos de freqüência Acartia lilljeborgi, Parvocalanus crassirostris, Oithona hebes, Corycaeus (C.) speciosus e Temora turbinata. A abundância mínima foi de 9 ind. $\mathrm{m}^{-3}$ e a máxima 2.532 ind. $\mathrm{m}^{-3}$. A média da diversidade de espécies foi 2,55 bits.ind $^{-1}$. De forma geral, a baía de Suape mostrou-se sob estresse ambiental grave e parece razoável concluir que as recentes modificações resultaram em mudanças na composição de espécies com aumento da influência marinha

\section{REFERENCES}

Araújo, H. and Montú, M. (1993), Novo registro de Temora turbinata (Dana, 1949) (Copepoda, Crustácea) para águas atlânticas. Nauplius, 1, 89-90.

Björnberg, T. S. (1981), Copepoda. In: Boltovskoy, D. (ed.). Atlas del zooplancton del Atlántico sudoccidental y métodos de trabajo con el zooplancton marino. Mar del Plata : INIDEP. pp. 587-679.

Boltovskoy, D. (1981), Atlas del zooplancton del Atlantico Sudoccidental y métodos de trabajo con el zooplancton marino. Mar del Plata : INIDEP. 936 pp.

Boltovskoy, D. (1999), South Atlantic Zooplankton. Leiden : Backhuys Publishers. 1706 pp.

Braga, R. A. P.; Moura, H. F. and Duarte, M. T. (1989), Impactos ambientais sobre a estrutura do manguezal de Suape. In: Universidade Federal de Pernambuco. Departamento de Biologia Geral. Laboratório de Ecologia. Avaliação de Impactos Ambientais em Zonas Estuarinas em Pernambuco. Recife. pp. 32-42. Carlton, J. T. (1989), Man's role in changing the face of the ocean: biological invasions and implications for conservation of near-shore environments. Conserv. Biol., 3, 265-273. 
Carlton, J. T. and Hodder, J. (1995), Biogeography and dispersal of coastal marine organisms: experimental studies on a replica of a $16^{\text {th }}$ century sailing vessel. Mar. Biol., 121, 721-730.

Cavalcanti, L. B.; Coelho, P. A.; Eskinazi-Leça, E.; Luna, J. A. C.; Macêdo, S. J. and Paranaguá, M. N. (1980), Condiciones ecologicas en el area de Suape (Pernambuco - Brasil). Paper presented at Seminario sobre el Estudio Cientifico y Impacto Humano en el Ecossistema de Manglares, Cali, 1978. Memorias del..., Montivideo, UNESCO, Oficina Regional de Ciência y Tecnologia para America Latina y el Caribe. pp. 243-256.

Connell, J. H. (1978), Diversity in tropical rain forests and coral reefs. Science, 199, 1302-1310.

Connell, J. H. (1980), Diversity and the coevolution of competitors or the ghost of competition past. Oikos, 35, 131-138.

Day Jr., J. W.; Hall, C. A. J.; Kemp, W. M. and YáñezArancibia, A. (1989), Estuarine Ecology. New York : Willey-Interscience Publication. pp. 311-337.

Day Jr., J. W.; Hopkinson, C. S. and Conner, W. H. (1982), An analysis of environmental factors regulating community metabolism and fisheries production in a Louisiana estuary. In: Kennedy, V. S. (ed.). Estuarine comparisons. New York : Academic Press. pp. 121-136.

Giller, P. S. (1984), Community structure and the niche. In: Dunet, G. M.; Gimingham, C. H. (eds.). Community structure and the niche. London : Chapman and Hall. 176 pp.

Heinle, D. R. and Flemer, D. (1975), Carbon requirements of a population of the estuarine copepod Eurytemora affinis. Mar. Biol., 31, 235-247.

Jonge, V. N. (1983), Relations between annual dredging activities, suspended matter concentrations and the development of the tidal regime in the Sem estuary. Can. J. Fish. Aquat. Sci., 40 : (Suppl. 1), 289-300.

Koening, M. L.; Eskinazi-Leça, E.; Neumann-Leitão, S. and Macêdo, S. J. Impactos da construção do porto de Suape sobre a comunidade fitoplanctônica no estuário do rio Ipojuca (Pernambuco-Brasil). Acta Bot. Bras., 16 : (4), 407-420, 2002.

Lima, D. A. and Costa, J. T. M. (1978), Flora e vegetação terrestres da área Programa Suape. Recife, Inst. Desenv. Pernambuco, Comunicação Técnica, 5, 1-24.

MacArthur, R. H. (1972), Geographical Ecology, Patterns in the Distribution of Species. New York : Harper and Row.

Melo Filho, J. A. S. (1977), Caracterização da situação atual da área Programa Suape sob o ponto de vista poluição ambiental. Recife, Inst. Desenv. Pernambuco, Comunicação Técnica, 1, 1-15.
Neumann, V. H.; Medeiros, C.; Parente, L.; NeumannLeitão, S. and Koening, M. L. (1998), Hydrodynamism, sedimentology, geomorphology and plankton changes at Suape area (Pernambuco Brazil) after a port complex implantation. Anais da Academia Brasileira de Ciências, 70 : (2), 313-323.

Neumann-Leitão, S. (1995), Resenha Literária Sobre Zooplâncton Estuarino no Brasil. Trab. Oceanogr. Univ. Fed. PE, 23, 25-53.

Neumann-Leitão, S.; Paranaguá, M. N. and Valentin, J. L. (1992a), Ecology of Planktonic Rotifera of the Estuarine Lagunar Complex at Suape, Pernambuco (Brazil). Hydrobiol., 232,133-143.

Neumann-Leitão, S.; Gusmão, L. M. O. and Nascimento-Vieira, D. A. (1992b), Zooplâncton dos estuários dos rios Massangana e Tatuoca, Suape (PE Brasil). Arq. Biol. Tecnol., 35 : (2), 341-360.

Neumann-Leitão, S.; Schwamborn, R.; Macêdo, S. J.; Medeiros, C.; Koening, M. L.; Montes, M. J. F.; Feitosa, F. A. N. and Gusmão, L. M. O. (2001), Plankton dynamics at Itamaracá mangrove estuarine system, Pernambuco, Brazil. In: Villacampa, Y.; Brebbia, C. A. and Uso, J. L. (eds.). Ecosystems and Sustainable Development III. Southhampton : Wit Press. pp. 435-446.

Omori, M. and Ikeda, T. (1984), Methods in marine zooplankton ecology. New York : Wiley-Interscience Publication. 331 pp.

Paranaguá, M. N. (1986), Zooplankton of the Suape area (Pernambuco- Brazil). Trab. Oceanogr. Univ. Fed. PE, 19, 113-124.

Pielou, E. C. (1977), Mathematical ecology. New York : Wiley. 385 pp.

Planka, E. R. (1978), Evoluntionary Ecology. $2^{\text {nd }}$ ed. New York : Harper and Row.

Ramos-Porto, M. and Lima, J. T. (1983), Estudos dos crustáceos decápodos da baía de Suape, Pernambuco. An. Soc. Nord. Zool., 1 : (1), 54.

Rickiefs, R. E. (1980), Ecology. $2^{\text {nd }}$ ed. England : Nelson, Walton on Thames.

Roman, M. R. (1984), Utilization of detritus by the copepod, Acartia tonsa. Limnol. Oceanogr., 29 : (5), 949-959.

Schwamborn, R. (1997), Influence of mangroves on community structure and nutrition of macrozooplankton in Northeast Brazil. Ph.D Thesis, Bremen University, Bremen, Alemanha.

Schwamborn, R.; Neumann-Leitão, S.; Silva, T. A.; Silva, A. P.; Ekau, W. and Saint-Paul, U. (2001), Distribution and dispersal of decapod crustacean larvae and other zooplankton in the Itamaracá estuarine system, Brazil. Tropical Oceanography, 29 : (1), 1-17.

Shannon, C. E. (1948), A mathematical theory of communication. Boll. Syst. Tech. J., 27, 379-423. 
Tregouboff, G. and Rose, M. (1957), Manuel de planctonologie Mediterranèenne. Centre Nacionale de la Recherche Scientifique, Paris.

Tundisi, J. G. (1970), O plâncton estuarino. Contr. avulsas Inst. Oceanogr. São Paulo, ser. Ocean. Biol., 19, 1-22.

Received: August 26, 2002;

Revised: June 02, 2003;

Accepted: November 21, 2003. 